УДК 347.9

DOI https://doi.org/10.17308/vsu.proc.law.2021.2/3392

\title{
ПОЛНОМОЧИЯ СУДА ПРИ ОТКАЗЕ ЛИЦА, ОБРАТИВШЕГОСЯ В СУД, ОТ ТРЕБОВАНИЯ О ПРИЗНАНИИ НОРМАТИВНОГО ПРАВОВОГО АКТА НЕДЕЙСТВУЮЩИМ: ТЕОРЕТИЧЕСКИЙ АНАЛИЗ И ЭМПИРИЧЕСКОЕ ИССЛЕДОВАНИЕ ДЕЙСТВУЮЩЕГО ПРАВОВОГО РЕГУЛИРОВАНИЯ
}

\author{
А. О. Вифлянцев \\ Национальный исследовательский университет \\ "Высшая школа эконолики" \\ Поступила в редакцию 23 декабря 2020 г.
}

\begin{abstract}
Аннотация: автор ставит в качестве основной цели поиск оптилального законодательного регулирования полнолочий суда в случае отказа лица, обратившегося в суд, от требования о признании норлативного правового акта недействующим и руководствуется следующили задачали: а) проанализировать с теоретической точки зрения особенность процедуры отказа заявителя от требования о признании нормативного правового акта недействующил; б) подвергнуть элпирическолу анализу основания решений судов при принятии отказов от иска по требованиял о признании норлативных правовых актов недействующили; в) сделать выводы с учетол политико-правовых оснований.

Ключевые слова: административное судопроизводство, оспаривание нормативных правовых актов, приниипь административного судопроизводства, публичный интерес, права сторон в адлинистративнол судопроизводстве, полномочия суда, активность суда, дискреиия суда.
\end{abstract}

Abstract: in the present paper the author aims to find the most optimal legislative regulation in terms of the court's authority in the aforementioned cases of claim withdrawal. The author is guided by following tasks: a) to analyse from a theoretical point of view the specifics of the procedure of withdrawing a claim to recognise a normative legal act as inoperative; b) to empirically analyse the reasoning behind the courts' decisions to accept withdrawals of claims to recognise normative legal acts as inoperative; c) to make conclusions with regards to political and legal reasoning.

Key words: administrative court proceedings, challenging normative legal acts, principles of administrative court proceedings, public interest, rights of the parties in administrative court proceedings, court power, court activity, judicial discretion.

Кодекс административного судопроизводства РФ ${ }^{1}$ (далее - КАС РФ) должен был совершить процессуальную революцию, не только сделав административное судопроизводство зримой правовой реальностью ${ }^{2}$, но

${ }^{1}$ Кодекс административного судопроизводства Российской Федерации : фе-дер. закон от 8 марта 2015 г. № 21-ФЗ (в ред. от 02.12.2019). Доступ из справ.-правовой системы «КонсультантПлюс».

${ }^{2}$ См.: Гролошина H. A. О принципе активности суда в административном судопроизводстве // Вестник гражданского процесса. 2019. № 4. С. 96-112.

(C) Вифрлянцев А. О., 2021 
и создав качественно новый уровень правосудия, который мог бы противодействовать злоупотреблениям исполнительной власти, государственных и муниципальных органов ${ }^{3}$. Переосмысления с позиций административного судопроизводства требовали и требуют многие процессуальные механизмы, в том числе процедура отказа лица, обратившегося в суд, от требования о признании нормативного правового акта недействующим.

Ученые-процессуалисты обращают внимание на то, что многие институты были заимствованы в неизменном виде из Гражданского процессуального кодекса $\Phi^{4}$ (далее - ГПК РФ) ${ }^{5}$ без должного осмысления правовых институтов ${ }^{6}$. В частности, примером такой нормы является п. 3 ст. 252 ГПК РФ, согласно которому «отказ лица, обратившегося в суд, от своего требования не влечет за собой прекращение производства по делу». В редакции ч. 10 ст. 213 КАС РФ это положение сорормулировано следующим образом: «Отказ лица, обратившегося в суд, от своего требования не влечет за собой обязанность суда прекратить производство по административному делу об оспаривании нормативного правового акта».

При буквальном толковании вышеуказанных норм их содержание внутренне противоречиво. С одной стороны, произошли существенные изменения в правовом регулировании: согласно ГПК РФ отказ заявителя от требования не приводил к прекращению производства по делу (ст. 252 ГПК РФ), в КАС РФ при применении данного полномочия речь идет уже об усмотрении суда (ст. 214 КАС РФ). С другой стороны, КАС РФ прямо не указывает даже на «ориентиры» судейского усмотрения, что необходимо при дискреции суда. Такой пробел в праве требует теоретического осмысления с помощью эмпирических данных.

\section{Теоретический аспект процедуры отказа лица, обратившегося в суд, от требования о признании нормативного правового акта недействующим}

Если «процесс есть осуществление материального права» ${ }^{7}$, а данная идея получила свое наибольшее отражение в цивилистическом процессе, то по общему правилу лицо должно обладать возможностью реализовывать распорядительные права, в том числе право на отказ от иска. В силу предоставления такого права административному истцу по делам об оспаривании нормативных правовых актов он может инициировать

${ }^{3}$ См.: Старилов Ю. Н. Административная юстиция : теория, история, перспективы. М., 2001.

${ }^{4}$ Гражданский процессуальный кодекс Российской Федерации : федер. закон от 14 ноября 2002 г. № 138-ФЗ. Доступ из справ.-правовой системы «КонсультантПлюс».

${ }^{5}$ URL: http://www.garant.ru/article/615444/

${ }^{6}$ Cм., например: Боннер А. T. Административное судопроизводство в Российской Федерации : мифр или реальность, или спор процессуалиста с административистом // Закон. 2016. № 7. С. 24-51; Его же. Вы хоть понимаете, что вы натворили? // Вестник университета имени О. Е. Кутафина. 2017. № 3(31). С. 26-33.

${ }^{7}$ Основополагающая идея немецкой материально-правовой теории иска. 


\section{Вестник ВГУ. Серия: Право}

отказ от требования о признании нормативного правового акта недействующим, после чего суд должен отреагировать на этот отказ с учетом того, что «воля суда, направленная на достижение указанной ему законом цели, есть та сила, которая связывает в одно целое отдельные действия как суда, так и других лиц, участвующих целей» .

Законодатель может закрепить за судом три варианта полномочий, а именно:

1) суд всегда обязан удовлетворять отказы лица, обратившегося в суд, от требования о признании нормативного правового акта недействующим;

2) суд всегда обязан отказывать в удовлетворении таких отказов от иска (либо сформулировать это положение иначе - запретить стороне отказываться от требования о признании нормативного правового акта недействующим);

3) суд имеет право оценивать отказ от требования о признании нормативного правового акта недействующим $a d$ hoc: в каких-то случаях отказ делать возможным, а в каких-то случаях нет.

Анализ данной части статьи сводится к обсуждению проблемы с позиций нормативного анализа, т. е. анализа того, каким должно быть законодательство, прежде всего, исходя из различных теоретических подходов. В таком контексте возникает вопрос: следует ли ограничивать свободу сторон при использовании ими распорядительных прав?

Мы не считаем, что предметом рассмотрения в административном судопроизводстве являются исключительно действия, затрагивающие частные интересы ${ }^{9}$. Такая логика, возможно, действительно применима к странам англо-саксонского права, где нормативные правовые акты исторически играли меньшую роль, чем в странах континентального

$\sim$ права. В данной конструкции логично позволить стороне отказаться от

이 требования о признании нормативного правового акта недействующим

Z без каких-либо ограничений. Однако в России, как и в других странах континентального права, такая логика применима не в полной мере. Более близким к пониманию российского административного судопроизводства является концепция М. Асимова, согласно которой административное судопроизводство обязано разрешать споры между государственными органами и частными лицами, которые образуются либо в связи с осуществлением государственного регулирования, либо в связи с распределением каких-либо льгот ${ }^{10}$. Соответственно, оспаривание нормативных правовых актов - споры в связи с осуществлением государственного регулирования, а значит, заинтересованность в споре не может быть

${ }^{8}$ Нефбедьев E. A. К учению о сущности гражданского процесса. Соучастие в гражданском процессе. Соучастие по немецкому и фрранцузскому праву // Недедьев Е. А. Избранные труды по гражданскому процессу. Краснодар, 2005.С. 232-237.

${ }^{9}$ Cм.: Setalvad $M$. C. Judicial review of administrative proceedings // Journal of the Indian Law Institute. Vol. 1, № 1 (Oct., 1958), p. 65-72.

${ }^{10}$ CM.: Asimow $M$. Five Models of Administrative Adjudication // American Journal of Comparative Law, Forthcoming Vol. 63, 2015, p. 1-48. 
только частной, так как прибыль от возможного итогового решения будет не эксклюзивной.

Кроме того, сами признаки нормативного правового акта как правовой сущности, перечисленные в постановлении Пленума Верховного Суда РФ от 25 декабря 2018 г. № 50 «О практике рассмотрения судами дел об оспаривании нормативных правовых актов и актов, содержащих разъяснения законодательства и обладающих нормативными свойствами» (далее - постановление Пленума ВС РФ № 50) 11 («наличие правовых норм (правил поведения), обязательных для неопределенного круга лиц, рассчитанных на неоднократное применение, направленных на урегулирование общественных отношений либо на изменение или прекращение существующих правоотношений») предполагают, что он распространяет свое действие не только на административного истца, но и еще на других лиц или, иными словами, истцом в материально-правовом смысле является неопределенный круг лиц ${ }^{12}$, что уже должно быть достаточным основанием для разумного ограничения реализации распорядительных прав.

Радикальным развитием данного тезиса является обоснование полного ограничения полномочий стороны по отказу от требования о признании нормативного правового акта недействующим, что выступает своеобразной презумпцией нарушения прав иных лиц, чьи права могут быть нарушены нормативным правовым актом. Учитывая, что по делам об оспаривании нормативных правовых актов наличие субъективной заинтересованности у заявителя является предпосылкой права на предъявление иска, а точнее, элементом процессуальной правоспособности, в дальнейшем же субъективная заинтересованность конкретного лица значения не имеет, так как определение правомерности оспариваемого акта всецело составляет задачу суда ex officio ${ }^{13}$. На наш взгляд, такая презумпция была бы излишним патернализмом.

Кроме того, полагаем, что данный институт должен быть более значимым процессуальным механизмом, чем предоставление права суду удовлетворять отказы от иска, когда нормативный правовой акт принимался в целях регулирования деятельности фрактически одного лица. Пункт 2 постановления Пленума ВС РФ № 50 предоставляет возможный альтернативный подход, согласно которому нормативный правовой акт может являться обязательныл для неопределенного круга лиц. Таким образом, фрактически допускается возможность, когда судопроизводство будет осуществляться по правилам главы 21 КАС РФ, но сам нормативный правовой акт будет применяться в отношении ограниченного круга лиц, а следовательно, публичный интерес, по крайней мере, в том смысле, в

11 Доступ из справ.-правовой системы «КонсультантПлюс».

${ }^{12}$ См.: Сахнова Т. В. Курс гражданского процесса. М., 2014. С. 233.

${ }^{13}$ См.: Ильин A. В. Конституционные основания осуществления нормоконтроля в гражданском процессе и предмет судебной деятельности // Вестник гражданского процесса. 2017. № 2. С. 31-46. 


\section{Вестник ВГУ. Серия: Право}

котором он используется в административном судопроизводстве, будет отсутствовать.

Удачным примером такого подхода, на наш взгляд, может быть следующий спор. Оспариваемым приказом РСТ Забайкальского края от 20 декабря 2016 г. № 577-НПА было введено тарифное регулирование на 2017-2021 гг. только в отношении административного истца, осуществляющего деятельность по захоронению твердых коммунальных отходов на территории муниципального образования городской округ город Чита ${ }^{14}$. Административный истец оспаривал вышеуказанный приказ по правилам главы 21 КАС РФ.

Таким образом, несмотря на то что по общему правилу исключение чьего-либо частного интереса не является основанием для прекращения производства по делам об оспаривании нормативных актов (поскольку в этом случае обязанность по защите публичного интереса с суда не снимается, и суд, рассматривая дело об оспаривании нормативных актов, связан данной обязанностью защитить публичный интерес и обязан рассмотреть оспариваемое положение в полном объеме независимо от доводов заинтересованных лиц $\left.{ }^{15}\right)$, но в приведенных нами примерах у суда отсутствуют основания для отказа в удовлетворении отказа от иска. Следовательно, институт отказа от иска будет существовать только в рамках таких исключительных случаев. В иных случаях правовое регулирование будет допускать всегда отказ от иска, что, как было уже показано выше, не может являться оптимальным решением.

Таким образом, два радикальных варианта (всегда удовлетворять и всегда отказывать) не являются оптимальным механизмом, а значит, основной теоретический и практический анализ сводится к ответу на вопрос о том, какими критериями должны руководствоваться суды при

принятии отказа от требования о признании нормативного правового 이 акта недействующим.

Первый вариант решения обозначенной проблемы состоит в законодательнол запрете принилать отказ лица, обратившегося в суд, от требования о признании норлативного правового акта недействуюшил в случае его противоречия "публичнылм интересал" ${ }^{16}$.

104 Традиционно в праве термин «публичные интересы» используется в контексте противопоставления частным интересам ${ }^{17}$. Более того, это одна

${ }_{14}$ Определение Забайкальского краевого суда от 25 мая 2017 г. по делу № 2А-52/2017 M-48/2017. Доступ из справ.-правовой системы «КонсультантПлюс".

${ }^{15}$ См.: Султанов А. Р. О праве заинтересованных лиц на обжалование решения по делу об оспаривании нормативного акта // Вестник гражданского процесca. 2016. № 5. С. 87-109.

${ }^{16}$ В КАС РФ термин «публичные интересы» упоминается шесть раз.

${ }^{17}$ См.: Пескова A. A. Баланс публичных и частных интересов при реализации права на судебную защиту муниципальной собственности // Конституционное и муниципальное право. 2010. № 10. С. 24 ; Лолаев А. Ю. Публичный интерес как правовая категория : автореф. дис. ... канд. юрид. наук. Казань, 2012 ; Бу- 
из старейших идей в праве ${ }^{18}$. Таким образом, например, Верховный Суд США активно развивал эту идею в конце 1930-х - начале 1940-х гг. при оценке конституционности законов, принятых в рамках нового курса Президента Рузвельта ${ }^{19}$.

В административном судопроизводстве такое деление по субъекту носителю материального права не является уместным. Под публичными интересами в данном случае следует понимать интересы общества в целом, т. е. имеющие «характер общечеловеческий, доступный и присущий всем людям независимо от социального статуса» ${ }^{20}$.

Несколько более удачно сорормулированной, на наш взгляд, является следующая дефиниция: «поведенческая реинкарнация таких классических категорий, как справедливость, всеобщая воля и общее благо» ${ }^{21}$. Схожим образом в российской правовой науке используется принцип законности. Так, Т. В. Сахнова писала, что «принцип законности состоит в том, что не только буква, но и «дух» закона должен быть воплощен в процессе и его результатах. Правосудие, естественно соотносимое со справедливостью, немыслимо без воплощения права в каждом конкретном деле, без толкования закона в соответствии с духом права» ${ }^{22}$. И именно интересы обеспечения законности, по мнению некоторых ученых, лежат в основе предоставления судам полномочий при отказе в удовлетворении отказа от требования о признании нормативного правового акта недействующим ${ }^{23}$.

Как представляется, методологическая разница между двумя вышеуказанными подходами отсутствует. В обоих случаях основанием для «блокировки» судом отказа от требования о признании нормативного правового акта недействующим являются интересы неопределенного круга лиц, которые определяются внутренним убеждением суда.

Таким образом, публичный интерес - это объективированные внутренние убеждения суда относительно идей справедливости, всеобщей воли и общего блага. При «широком варианте» право в лице суда должно блокировать отказ от иска в случае противоречия такого отказа публич-

блик B. A. Публично- и частноправовые начала в гражданско-правовом регулировании внешнеэкономической деятельности : дис. ... д-ра юрид. наук. Екатеринбург, 2000.

${ }^{18}$ Cм.: Graziano L. On Special Interests, Public Interests, and Unequal Represen-

ation // International Political Science Review, Vol. 17, № 3, Jul., 1996, p. 307-317.

${ }^{19}$ См.: Бельх С. В. Принцип справедливого равновесия между частными и публичными интересами в свете отдельных судебных решений // Бизнес, менеджмент и право. 2017. № 3/4. С. 14-16.

${ }^{20}$ Иванова И. А. О некоторых вопросах правового регулирования института судебного нормоконтроля в административном судопроизводстве // Административное и муниципальное право. 2018. № 5. С. 37-45.

${ }^{21}$ Graziano L. Op. cit.

${ }^{22}$ Сахнова Т. В. Указ. соч. С. 145.

${ }^{23}$ См., например: Зелениов А. Б., Ястребов О. А. Судебное административное право : учеб. для студ. вузов, обучающихся по специальности «Юриспруденция». M., 2017. 
ным интересам. Фактически это означает, что суд в каждом конкретном случае, полагаясь на свои внутренние убеждения, будет производить оценку возможного противоречия публичным интересам.

Второй вариант решения обозначенной проблель состоит в законодательнол запрете принимать отказ лииа, обратившегося в суд, от требования о признании нормативного правового акта недействующил в случае нарушения прав и законных интересов других лии таким отказол.

Отличием первого варианта от второго следует считать уход от абстрактной категории "публичные интересы» к нарушению конкретной нормы закона или нарушению конкретного права лица. Аргументы contra первого варианта и соответственно в пользу второго варианта состоят, во-первых, в указании на сложность или даже невозможность определения публичных интересов, а во-вторых, в критике использования публичных интересов как ориентира права.

Авторы, которые черпали вдохновение из произведений Е. Е. Шатшнайдера ${ }^{24}$, категорически отрицают существование такого понятия, как публичный интерес - существует множество общественных интересов. В любом конкретном споре может быть несколько противоречий, например защита окружающей среды против экономического развития и национальная безопасность против свободного доступа к информации ${ }^{25}$. Таким образом, публичными интересами в контексте судебного спора будут не конкретные нарушения закона и права, а моральные установки конкретного судьи в контексте конкретного спора. Фактически такая ситуация будет означать, что деятельность суда будет лишена важной составляющей - прогнозируемости действия суда, чтобы стороны могли формировать свою деятельность исходя из четких ожиданий.

$\sim \quad$ Возможным доводом contra первого подхода будет также то, что суды

을 не должны быть заинтересованы в увеличении общественного благосостояния, этим занимаются другие ветви власти ${ }^{26}$. Административное судопроизводство призвано защищать нарушенное право конкретного лица. Это означает, что в случае отказа лица, обратившегося в суд, от требования о признании нормативного правового акта недействующим,

106 суд должен исследовать его на предмет нарушения права конкретного лица, а не вдаваться в абстрактные размышления о возможном нарушении публичных интересов.

\section{Политико-правовые основания для законодательного регулирования}

Абсолютное большинство проблем в сфере должного законодательного регулирования сводятся к дискуссии о том, издержки от какого вы-

${ }^{24}$ Cм., например: Schlozman K. L., Tierney J. T. Organized Interests and American Democracy. New York, 1986.

${ }^{25}$ См.: Graziano L. Op. cit.

${ }^{26}$ Cм.: Setalvad M. C. Op. cit. 
бора будут минимальными: от ошибок I рода (false positive), когда право запрещает то, что должно быть разрешено при точечном контроле исходя из политико-правовых оснований, или от ошибок II рода (ложноотрицательных результатов, false negative), когда право ограничивает действия там, где ограничений не должно быть ${ }^{27}$. Применительно к данному случаю вопрос будет звучать следующим образом: должна ли дискреция суда сводиться к расширительному толкованию возможных объектов нарушения прав или к узкому? Что лучше - излишний патернализм и забота о возможных нарушенных правах широкого круга лиц путем продолжения судебного процесса, несмотря на потерю интереса сторон к итогу спора, или «блокировка» отказов от иска только в случае наличия нарушения прав конкретного лица или конкретной нормы закона, которая нарушена, что допускает "пропуск» тех дел, где конкретного лица нет, но по моральным соображениям мы не должны его пропускать?

Учитывая специфику дел и задачи административного судопроизводства, а также возможные последствия неудовлетворения отказа от иска и продолжение рассмотрения спора по существу и вынесение решения, защита публичных интересов имеет логичную и соответствующую смыслу действующего законодательства основу, поскольку вступившее в законную силу решение суда по делу об оспаривании нормативного правового акта носит публичный характер и является обязательным для всех лиц, как участвующих, так и не участвующих в рассмотрении данного дела.

Единственный способ защищать интересы этих лиц заключается в наделении суда бо́льшими полномочиями. Представляется также, что наличие ошибок II рода не критично, а возможно, даже в некотором смысле положительно, если суд решит установить фактические обстоятельства дела и вынести решение по существу, даже если по каким-то причинам стороны потеряют интерес к итогу спора, и суд будет по собственной инициативе устанавливать фактические обстоятельства. Серьезным аргументом contra вышеприведенным рассуждениям может быть то, что исходя из принципа процессуальной экономии законодательство должно отдавать предпочтение узкому толкованию ${ }^{28}$. Иными словами, в чем состоит смысл продолжать судопроизводство по собственной инициативе суда, фрактически с дальнейшей деятельностью по сбору доказательств, если административный истец уже считает нужным отказаться от иска? Не вдаваясь в дискуссии о наличии или отсутствии принципа процессуальной экономии в административном судопроизводстве, следует отме-

${ }^{27}$ См.: Kapanemoв А. Г. Экономический анализ права. М., 2016 ; Шастит-

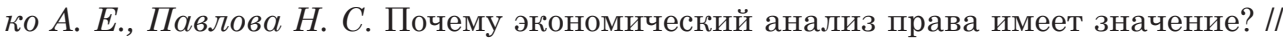
Закон. 2018. № 3. С. 57-66.

${ }^{28}$ См. подробнее: Иванова И. А. О некоторых вопросах правового регулирования института судебного нормоконтроля в административном судопроизводстве // Административное и муниципальное право. 2018. № 5. С. 37-45. 
тить, что идея экономии в любом случае верная - неоправданную трату ресурсов, если она является таковой, законодательство должно исключать. Тем не менее не считаем, что трата ресурсов в данном случае не оправдана исходя из того, что нормативный правовой акт распространяет свое действие на неограниченный круг лиц. Исходя из этого отступление от принципа процессуальной экономии в данном случае представляется обоснованным.

\section{Эмпирический анализ оснований принятия решений судов в России в случае отказа от иска}

Согласно действующему законодательству отказ лица, обратившегося в суд, от своего требования не влечет за собой обязанность суда прекратить производство по административному делу об оспаривании нормативного правового акта (ч. 10 ст. 213 КАС РФ). Таким образом, полномочие суда прекратить производство по делу в этом случае сформулировано как его право, а следовательно, решение вопроса о принятии отказа от иска и прекращение производства по делу остается на усмотрение суда ${ }^{29}$.

Данное положение, по всей видимости, следует рассматривать в системной связи с общей нормой ч. 5 ст. 46 КАС РФ ${ }^{30}$ и специальной нормой п. 2 ч. 2 ст. 214 КАС РФ ${ }^{31}$. Именно таким путем идет Верховный Суд РФ в решениях по конкретным делам ${ }^{32}$. Фактически такая взаимосвязь приводит к тому, что Верховный Суд РФ толкует основания для отказа максимально широко, принимая во внимание как нарушение прав отказом лиц, не участвующих в процессе, так и нарушение публичных интересов.

Нижестоящие суды руководствуются подходом Верховного Суда РФ, развивая его в том же направлении с учетом фактических обстоятельств дела. Судами, например, были выведены следующие критерии надлежа인 щего отказа от иска:

- отказ истиа от заявленных требований подписан уполнолоченнылм в соответствии с учредительныли докулентали (Уставол общества) лицол, не противоречит закону и не нарушает права и охраняемые законом интересы других лиц. Последствия отказа от заявленных

${ }^{29}$ См.: Иванова И. А. Указ. соч.

${ }^{30}$ Суд не принимает отказ административного истца от административного иска, если это противоречит Кодексу административного судопроизводства Российской Федерации, другим федеральным законам или нарушает права других лиц.

${ }^{31}$ Суд вправе прекратить производство по административному делу об оспаривании нормативного правового акта в случае, если лицо, обратившееся в суд, отказалось от своего требования и отсутствуют публичные интересы, препятствующие принятию судом данного отказа.

${ }^{32}$ Определение Судебной коллегии по административным делам Верховного Суда РФ от 19 мая 2017 г. № 8-АПГ17-2 ; определение Апелляционной коллегии Верховного Суда РФ от 6 сентября 2018 г. № АПЛ18-327. Доступ из справ.-правовой системы «КонсультантПлюс». 
требований и прекращения производства по делу административному

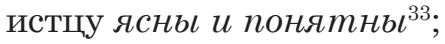

- по данной категории административных дел допускается принятие отказа от административного иска, последствия отказа от административного иска административному истцу разъяснены, отказ не противоречит закону, не нарушает права и законные интересы сторон и других лиц, публичные интересы, препятствуюшие принятию судол данного отказа, отсутствуют ${ }^{34}$;

- суд полагает возможным принять отказ от административного иска, поскольку он заявлен добровольно, не противоречит закону и не нарушает права других лии, административному истцу понятны последствия прекращения производства по делу ${ }^{35}$;

- отказ от административного иска административным истцом совершен добровольно, последствия отказа от административного иска, предусмотренные ст. 195 КАС РФ, представителю административного истца разъяснены и понятны.

При таких данных отказ от административного иска не противоречит настояшелу кодексу, другил фбедеральныл законал и не нарушает права других лии, в связи с чем подлежит принятию судом с прекращением производства по делу ${ }^{36}$;

- отказ от требований подписан представителем административного истца, у которого есть право на отказ от иска, предусмотренное доверенностью, в тексте заявления указано, что последствия отказа от исковых требований известны и понятны.

С учетом изложенного, принимая во внимание то обстоятельство, что оспариваемый нормативный правовой акт касается правового регулирования объектов, принадлежащих административному истцу, публичные интересы, препятствующие принятию судом данного отказа, отсутствуют, сам отказ является добровольным, не противоречит требованиям закона и не нарушает права других лиц, связан с отсутствием спора с административным ответчиком, суд считает возможным принять отказ от административного искового заявления ${ }^{37}$;

${ }_{33}$ Определение Забайкальского краевого суда от 25 мая 2017 г. по делу № 2A-52/2017 M-48/2017. Доступ из справ.-правовой системы «КонсультантПлюс».

${ }^{34}$ Определение Усть-Вымского районного суда Республики Коми от 8 апреля 2016 г. по делу № 2А-34/2016. Доступ из справ.-правовой системы «КонсультантПлюс».

${ }^{35}$ Определение Белгородского областного суда от 2 ноября 2016 г. по делу № 3а-160/2016. Доступ из справ.-правовой системы «КонсультантПлюс».

${ }^{36}$ Определение Кемеровского областного суда от 20 февраля 2016 г. по делу № 3А-117/2016 M-1224/2015. Доступ из справ.-правовой системы «КонсультантПлюс».

${ }^{37}$ Определение Московского городского суда от 15 декабря 2017 г. по делу № 3а-3014/2017. Доступ из справ.-правовой системы «КонсультантПлюс». 
- суд принимает отказ истца от иска, поскольку из представленных суду доказательств следует, что в настоящее время разрешение данного заявления прокурора по существу утратило свою актуальность, так как обстоятельства, послужившие основанием для обращения прокурора в суд с таким заявлением, отпали, поскольку требования фрактически добровольно исполнены ответчиками после подачи прокурором заявления в суд ${ }^{38}$.

В то же время судами были разработаны следующие основания для признания отказа от иска незаконным и соответственно для отказа принятия такого отказа:

- отказ от административного искового заявления обусловлен предположением о том, что обстоятельства, послужившие основанием для подачи административного иска, фрактически будут устранены во внесудебном порядке. Апелляционная коллегия полагает, что отсутствуют основания для принятия отказа от иска и прекращения производства по делу, поскольку настоящее административное дело о проверке законности оспариваемого положения нормативного правового акта затрагивает публичные интересы, права и охраняемые законом интересы неопределенного круга лиц, что препятствует принятию судом отказа от административного иска ${ }^{39}$;

- отказ от административного искового заявления противоречит закону, нарушает права других лиц, публичные интересы, т. е. имеются обстоятельства, препятствующие принятию судом данного отказа. При этом Судебной коллегией учитывается взаимосвязь положений норм, от оспаривания которых административные истцы отказываются с положениями норм, на признании которых недействующими они настаивают $^{40}$.

Как видно из решений судов, на практике в настоящее время наибольшее внимание уделяется соответствию формальным основаниям для отказа. Квинтэссенция такой позиции - соответствие фрормальных оснований закону как доказательство отсутствия нарушения норм КАС РФ и прав третьих лиц. Продолжая последовательное развитие такой позиции, следует обратить внимание на отношение судей к отказу от иска со стороны прокурора. Прокурор, как правило, обращается в суд с административным исковым заявлением в защиту прав, свобод и законных интересов граждан, неопределенного круга лиц или интересов Российской Федерации, субъектов РФ, муниципальных образований, т. е. фрактически того, что и должно составлять публичный интерес. В производстве прокурор отказывается от административного иска, посчитав, например,

${ }^{38}$ Определение Фрунзенского районного суда г. Иваново от 20 февраля 2017 г. по делу № 2-482/2017. Доступ из справ.-правовой системы «КонсультантПлюс».

${ }^{39}$ Определение Апелляционной коллегии Верховного Суда РФ от 6 сентября 2018 г. № АПЛ18-327. Доступ из справ.-правовой системы «КонсультантПлюс».

${ }^{40}$ Определение Судебной коллегии по административным делам Верховного Суда РФ от 19 мая 2017 г. № 8-АПГ17-2. Доступ из справ.-правовой системы «КонсультантПлюс». 
что «отсутствует спор»"1. Суды не видят здесь логического противоречия и удовлетворяют такие отказы ${ }^{42}$. Таким образом, суды на практике прежде всего наблюдают за формальными основаниями отказа от иска и только в некоторых случаях (по всей видимости, когда отказ вступает в противоречие с правовой интуицией судьи) суд отказывает в связи с противоречием закону и публичным интересам.

Приведенный выше анализ судебной практики, а также системного толкования норм КАС РФ со стороны Верховного Суда РФ приводит к мысли о том, что в настоящее время суды используют ч. 10 ст. 213 КАС РФ как «скальпель» для отсечения тех отказов от иска, которые по внутреннему убеждению суда не должны поощряться правопорядком ${ }^{43}$. Заметим, что проблемой является не просто использование такого «скальпеля», а использование его интуитивно, без телеологического анализа института. Отдельной критики заслуживает юридическая техника действующего законодательного регулирования. «Разграничение» оснований для прекращения производства по делу судом (п. 2 ч. 2 ст. 214 КАС РФ) и закрепление принципа отсутствия императивного правила для суда принимать иск отрицательно сказываются на понимании судами тех целей КАС РФ, которые преследуются при предоставлении дискреционного полномочия судам.

Положительной оценки, на наш взгляд, заслуживает разработанная терминология ст. 168 и 169 ГК РФ, где критерии блокировки действий правом должны подпадать под следующие характеристики: «противная основам правопорядка или нравственности, нарушающая требования закона или иного правового акта и при этом посягающая на публичные интересы либо права и охраняемые законом интересы третьих лиц». На наш взгляд, такие критерии более конкретно устанавливают ориентиры для судов при принятии решения в случае отказа административного истца от требования о признании нормативного правового акта недействующим.

Таким образом, предлагаем изложить ч. 10 ст. 213 КАС РФ в следующей редакции: «Отказ лица, обратившегося в суд, от требования о признании нормативного правового акта недействующим не влечет за собой обязанность суда прекратить производство по административному делу об оспаривании нормативного правового акта. Суд обязан проверить такой отказ на противоречие публичным интересам и правам и охраняемым законом интересы третьих лиц. Публичные интересы могут выражаться в нарушении основ правопорядка или нравственности, требований закона или иного правового акта. В случае отсутствия проти-

${ }^{41}$ Определение Московского городского суда от 29 января 2016 г. по делу № 3а117/2016. Доступ из справ.-правовой системы «КонсультантПлюс».

42 Там же.

${ }^{43}$ По аналогии с метким определением Р. С. Бевзенко для института «добросовестности». URL: https://zakon.ru/blog/2019/8/20/analiz_tezisov_o_principe_dobrosovestnosti_v_grazhdanskom_prave 


\section{Вестник ВГУ. Серия: Право}

воречия публичным интересам, а также при соблюдении формальных требований к отказу от нормативного правового акта суд удовлетворяет такой отказ и прекращает производство по административному делу».

\section{Библиографический список}

Бельх C. В. Принцип справедливого равновесия между частными и публичными интересами в свете отдельных судебных решений // Бизнес, Менеджмент и Право. 2017. № 3/4. С. 14-16.

Боннер А. Т. Административное судопроизводство в Российской Федерации : миф или реальность, или спор процессуалиста с административистом // Закон. 2016. № 7. С. 24-51.

Боннер А. Т. Вы хоть понимаете, что вы натворили? // Вестник Университета имени О. Е. Кутафина. 2017. № 3(31). С. 26-33.

Бублик B. A. Публично- и частноправовые начала в гражданско-правовом регулировании внешнеэкономической деятельности : дис. ... д-ра юрид. наук. Екатеринбург, 2000.

Гролошина Н. А. О принципе активности суда в административном судопроизводстве // Вестник гражданского процесса. 2019. № 4. С. 96-112.

Гурвич М. А. Право на иск. Л. : Изд-во АН СССР, 1949. 216 с.

Зелениов А. Б., Ястребов О. А. Судебное административное право : учеб. для студ. вузов, обучающихся по специальности «Юриспруденция». М. : Статут, 2017. 768 с.

Иванова И. А. О некоторых вопросах правового регулирования института судебного нормоконтроля в административном судопроизводстве // Административное и муниципальное право. 2018. № 5. С. 37-45.

Ильин A. B. Конституционные основания осуществления нормоконтроля в гражданском процессе и предмет судебной деятельности // Вестник гражданского процесса. 2017. № 2. С. 31-46.

Карапетов А. Г. Экономический анализ права. М. : Статут, 2016. 528 с.

Лолаев А. Ю. Публичный интерес как правовая категория : авторефр.

근. дис. ... канд. юрид. наук. Казань, 2012.

Меркуро Н., Медела С. Экономическая теория и право : от Познера к постмодернизму и далее. М. : Изд-во Института Гайдара, 2019. 520 с.

Нефбедьев $E$. A. К учению о сущности гражданского процесса. Соучастие в гражданском процессе. Соучастие по немецкому и фрранцузскому праву // Не-

112 федьев Е. А. Избранные труды по гражданскому процессу. Краснодар, 2005. C. 232-237.

Пескова A. А. Баланс публичных и частных интересов при реализации права на судебную защиту муниципальной собственности // Конституционное и муниципальное право. 2010. № 10. С. 24-28.

Сахнова Т. В. Курс гражданского процесса. М. : Статут, 2014. 784 с.

Старилов Ю. Н. Административная юстиция. Теория, история, перспективы. М. : НОРМА, 2001. 304 с.

Султанов A. P. О праве заинтересованных лиц на обжалование решения по делу об оспаривании нормативного акта // Вестник гражданского процесca. 2016. № 5. С. 87-109.

Шаститко A. E., Павлова H. C. Почему экономический анализ права имеет значение? // Закон. 2018. № 3. С. 57-66. 
Шершеневич Г. Ф. Общая теория права : учеб. пособие : в 2 т. М., 1995. T. 2 .

Asimow M. Five Models of Administrative Adjudication // American Journal of Comparative Law, Forthcoming. 2015. Vol. 63. P. 1-48.

Graziano L. On Special Interests, Public Interests, and Unequal Representation // International Political Science Review. Vol. 17, No. 3, Jul., 1996. P. 307317.

Setalvad M. C. Judicial review of administrative proceedings // Journal of the Indian Law Institute. Oct., 1958. Vol. 1, No. 1. P. 65-72.

Schlozman K. L., Tierney J. T. Organized Interests and American Democracy. New York: Harper \& Row. 1986.

\section{References}

Belykh S. V. The principle of equitable equilibrium between private and public interests in the light of individual court decisions // Business, management and law. 2017. No. 3/4. P. 14-16.

Bonner A. T. Administrative proceedings in the Russian Federation : a myth or reality, or a proceeding of a procedural administrative system // Law. 2016. No. 7. P. 24-51.

Bonner A. T. Do you even understand what you have done? // Bulletin University named after O. E. Kutafina. 2017. No. 3 (31). P. 26-33.

Bublik V. A. Publicly and private started in civil law regulation of foreign economic activity : dis. ... dr of legal sciences. Yekaterinburg, 2000.

Gromina N. A. On the principle of court activity in administrative proceedings // Bulletin of the Civil Process. 2019. No. 4. P. 96-112.

Gurvich M. A. The right to lawsuit. L. : Publishing House of the Academy of Sciences of the USSR, 1949. $216 \mathrm{p}$.

Zelentsov A. B., Yastrebov O.A. Judicial administrative law : a textbook for students of universities, students in the specialty "Jurisprudence". M. : Statute, 2017. 768 p.

Ivanova I. A. On some issues of legal regulation of the Institute of Judicial Normocontrol in administrative proceedings // Administrative and municipal law. 2018. No. 5. P. 37-45.

Ilyin $A$. $V$. Constitutional reasons for the implementation of the normocontrol in the civil procedure and the subject of judicial activity // The Bulletin of the Civil Process. 2017. No. 2. P. 31-46.

Karapetov A. G. Economic analysis of law. M. : Statute, 2016. 528 p.

Lomayev A. Yu. Public interest as legal category : author. Dis. ... Cand. jurid. science. Kazan, 2012.

Merkuro N., Medema C. Economic theory and right: from Posner to postmodernism and further. M. : Publishing House of the Gaidar Institute, 2019. 520 p.

Nefedyev E. A. To the teachings on the essence of the civil process. Complicity in civil process. Complicity in German and French law // Nefedyev E. A. Selected works of civil proceedings. P. 232-237.

Peskova A. A. Balance of public and private interests in the realization of the right to judicial protection of municipal property // Constitutional and municipal law. 2010. No. 10. P. 24-28.

Sakhnova T. V. Course Court. M. : Statute, 2014. 784 p. 
Starilov Yu. N. Administrative justice. Theory, history, perspectives. M. : Publisher Norma, 2001. 304 p.

Sultanov A. R. On the right of stakeholders to appeal the decision on the challenge of the regulatory act // Bulletin of the Civil Process. 2016. No. 5. P. 87-109.

Shastitko A. E., Pavlova N. S. Why does economic analysis of law matters? // Law. 2018. No. 3. P. 57-66.

Shershenevich G. F. General Theory of Law : Tutorial. In 2 volumes. M., 1995. Vol. 2.

Asimow M. Five Models of Administrative Adjudication, American Journal of Comparative Law, Forthcoming. 2015. Vol. 63. P. 1-48.

Graziano L. On Special Interests, Public Interests, and Unequal Representation // International Political Science Review. Vol. 17, No. 3. Jul., 1996. P. 307317.

Setalvad M. C. Judicial review of administrative proceedings // Journal of the Indian Law Institute. Oct., 1958. Vol. 1, No. 1. P. 65-72.

Schlozman K. L., Tierney J. T. Organized Interests and American Democracy. New York : Harper \& Row, 1986.

Национальный исследовательский университет "Высшая школа экономикu»

Вифбляниев А. О., аспирант, юрист в ПАО «СИТИ»

E-mail:aoviflyantsev@gmail.com
National Research University "Higher School of Economics"

Viflyantsev A. O., Post-graduate Student, Lawyer in PJSC "CITY"

E-mail: aoviflyantsev@gmail.com 